\title{
Bioelectrochemical Oxidation of Water
}

Marcos Pita*a, Diana M. Mate ${ }^{\mathrm{a}}$, David Gonzalez-Perez ${ }^{\mathrm{a}}$, Sergey Shleev ${ }^{\mathrm{b}}$, Victor M. Fernandez ${ }^{\mathrm{a}}$, Miguel Alcalde ${ }^{\mathrm{a}}$, Antonio L. De Lacey *a ${ }^{\text {. }}$

${ }^{a}$ Instituto de Catalisis y Petroleoquimica, CSIC. C/ Marie Curie, 2, L10. 28049 Madrid, Spain.

${ }^{\mathrm{b}}$ Department of Biomedical Sciences, Faculty of Health and Society, Malmö University, 20560 Malmö, Sweden.

Publication Date (Web): April 11, 2014

This article should be cited as:

J. Am. Chem. Soc., 2014, 136 (16), pp 5892-5895. DOI: 10.1021/ja502044j

\begin{abstract}
The electrolysis of water provides a link between electrical energy and hydrogen, a high energy density fuel and a versatile energy carrier, but the process is very expensive ${ }^{1}$. Indeed, the main challenge is to reduce energy consumption for large-scale applications using efficient renewable catalysts, which can be produced at low cost. Here we present for the first time that laccase can catalyse electrooxidation of $\mathrm{H}_{2} \mathrm{O}$ to molecular oxygen. Native and laboratory evolved laccases immobilized onto electrodes serve as bioelectrocatalytic systems with low overpotential and a high $\mathrm{O}_{2}$ evolution ratio against $\mathrm{H}_{2} \mathrm{O}_{2}$ production during $\mathrm{H}_{2} \mathrm{O}$ electrolysis. Our results open a new research ground on $\mathrm{H}_{2} \mathrm{O}$ splitting as they allow overcoming serious practical limitations associated with artificial electrocatalysts used for $\mathrm{O}_{2}$ evolution nowadays.
\end{abstract}

\section{ARTICLE}

Water $\left(\mathrm{H}_{2} \mathrm{O}\right)$ splitting has been a top matter of research for decades ${ }^{2,3}$. In particular, $\mathrm{H}_{2} \mathrm{O}$ electrolysis is a very accessible route to synthesize hydrogen $\left(\mathrm{H}_{2}\right)$, a high energy density fuel and a versatile energy carrier, while avoiding the use of hydrocarbon sources. $\mathrm{H}_{2} \mathrm{O}$ electrolysis requires two electrodes, the cathode for $\mathrm{H}_{2}$ evolution and the anode for oxygen $\left(\mathrm{O}_{2}\right)$ production. The main hinder to accomplish $\mathrm{H}_{2} \mathrm{O}$ electrolysis is to find appropriate catalysts to perform both redox reactions with high turnover rates at low overpotentials. Accordingly, enzymatic redox systems can provide needed characteristics. $\mathrm{O}_{2}$ tolerant hydrogenases are considered as efficient bioelectrocalalysts for $\mathrm{H}_{2}$ production ${ }^{4,5}$. However, no enzyme with ability to electrocatalytically oxidize $\mathrm{H}_{2} \mathrm{O}$ to $\mathrm{O}_{2}$ besides photosystem II (PSII) has been identified so far, whereas the $\mathrm{O}_{2}$ electrode has a substantial effect on the performance and durability of $\mathrm{H}_{2} \mathrm{O}$ electrolyzers because of its intrinsically slow kinetics and poor durability. Indeed, it is possible to link PSII to an electrode and oxidize $\mathrm{H}_{2} \mathrm{O}$ to $\mathrm{O}_{2}$ with sunlight assistance ${ }^{6}$, but its size, lack of stability and complexity makes the task overwhelming. Here we present such an enzyme, laccase, which can catalyze $\mathrm{O}_{2}$ production from $\mathrm{H}_{2} \mathrm{O}$ by direct electron transfer of electrons to a polarized electrode. In other words, for the first time we show $\mathrm{O}_{2}$ evolution/reduction electrocatalyzed by fungal oxidoreductases at potentials close to the redox equilibrium potential of $\mathrm{O}_{2} / \mathrm{H}_{2} \mathrm{O}$ couple ${ }^{7}$, i.e. $0.98 \mathrm{~V}$ and $0.79 \mathrm{~V} v$ s. NHE at $\mathrm{pH}$ 4.2 and $\mathrm{pH} 7.4$, respectively.

Fungal laccases are blue multicopper oxidases with an active site populated by four copper $(\mathrm{Cu}) \mathrm{cat}-$ ions that catalyzes the oxidization of many organic and inorganic compounds using $\mathrm{O}_{2}$ as the only electron acceptor, generally at acidic values of $\mathrm{pH}$ (Figure 1$)^{8}$. The catalytic mechanism of laccases involves the oxidation of the substrate at the T1 copper $(\mathrm{Cu})$ site with the concomitant reduction of $\mathrm{O}_{2}$ to $\mathrm{H}_{2} \mathrm{O}$ in a trinuclear $\mathrm{Cu}$ cluster (T2/T3 $\mathrm{Cu}$ cluster) placed 12-13 $\AA$ away, without releasing $\mathrm{H}_{2} \mathrm{O}_{2}{ }^{9}$. Taking into account the differences in redox potentials between the $\mathrm{O}_{2} / \mathrm{H}_{2} \mathrm{O}$ couple and the reduced/oxidized substrate couples (phenolic compounds, anilines, metal complexes, etc.), the reverse reaction in a homogeneous system, i.e. $\mathrm{O}_{2}$ production from $\mathrm{H}_{2} \mathrm{O}$ with concomitant reduction of an oxidized substrate, is 
thermodynamically impeded due to the very positive free Gibbs energy value for this process. However, this limitation can be overcome in heterogeneous bioelectrocatalytic systems since the reaction driving force is regulated by the potential applied externally. The point is that laccase was the very first enzyme for which direct electron transfer biolectrocatalysis was shown as early as in $1978^{10}$. However, to the best of our knowledge, it has never been reported any kind of reverse activity for this oxidoreductase, i.e. $\mathrm{H}_{2} \mathrm{O}$ oxidation through the $\mathrm{Cu}$ cluster, although the enzyme has been broadly used as bioelectrocatalyst for $\mathrm{O}_{2}$ reduction ${ }^{11,12}$. Taking into account that $\mathrm{O}_{2}$ production using several $\mathrm{Cu}$ complexes as artificial electrocatalysts has already been reported ${ }^{13}$, we have studied the conditions at which the reverse electrochemical behaviour of this multicopper oxidase may take place.

A

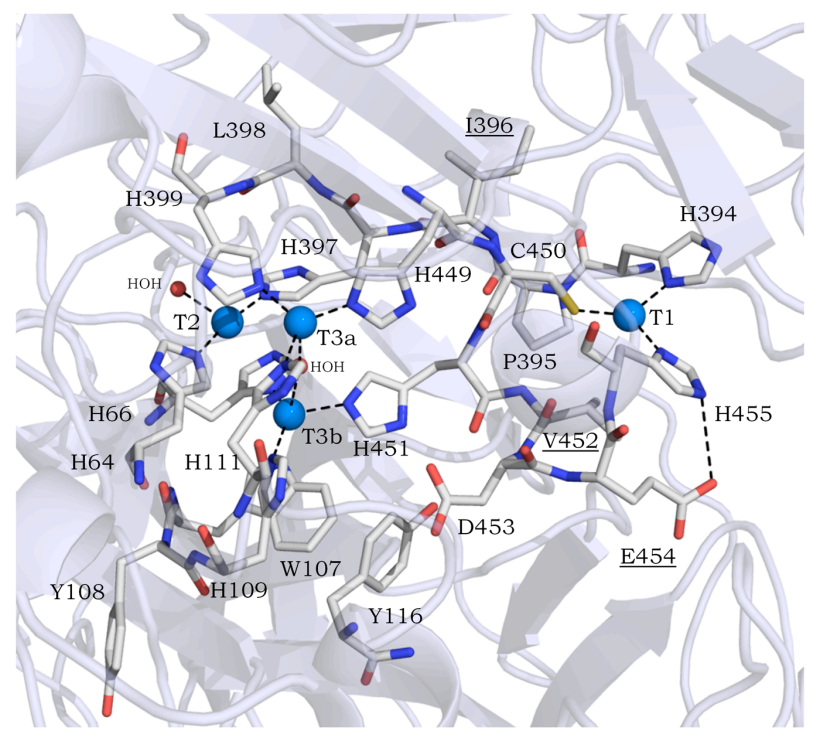

B

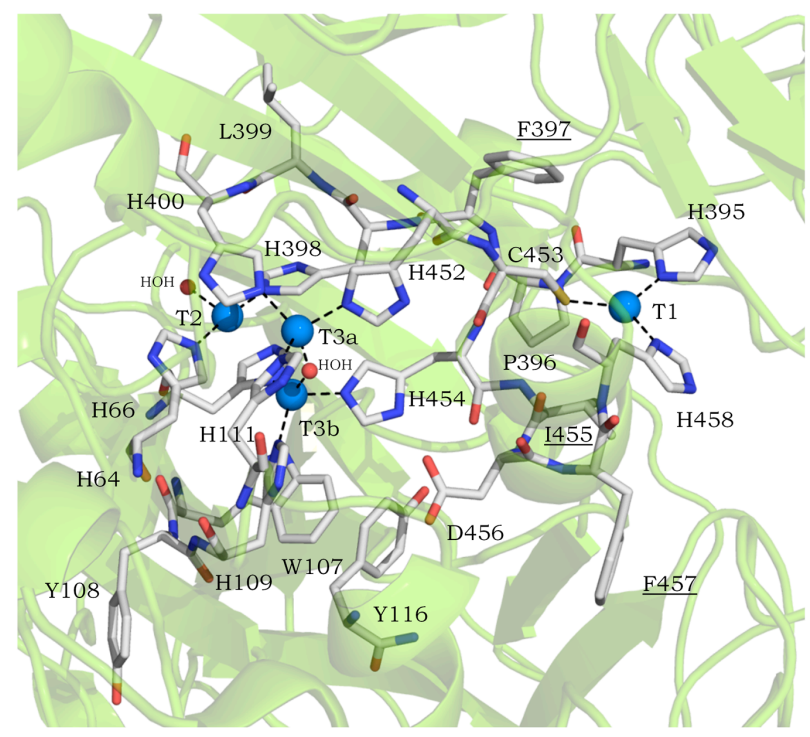

Figure 1. Structural details for the active site of ChU-B mutant (A) and ThLc (B). Amino acid residues are highlighted in stick mode and coloured as CPK code. Overall structures are shown as cartoon mode. Copper ions are shown as spheres in blue and water molecules as red spheres. Dash lines indicate interactions between copper ions and amino acids involved in the active site. The mutations introduced in ChU-B are underlined. ChU-B mutant was modelled using the template $2 \mathrm{HRG}$ of the Trametes trogii laccase (97\% of sequence identity with ChU-B); ThLc model was from structure PDB ID:3FPX entry.

Our first strategy focused on bonding a wild type high redox potential laccase (Trametes hirsuta laccase, ThLc) on low-density graphite (LDG) electrodes modified with aminoaryl groups ${ }^{14,15}$ (ThLcLDG), Figure 2A. LDG was chosen as electrode material due to its high overpotential towards $\mathrm{O}_{2}$ production in an electrolytic experiment, particularly when compared with Pt or even Au. This selection facilitates attributing the results to the presence of laccase on its surface. The first test carried out with ThLc-LDG was to check its standard activity of reducing $\mathrm{O}_{2}$ at acidic $\mathrm{pH}$ by cyclic voltammetry (CV). Under these conditions a typical bioelectrocatalytic current plateau of $c a$. $-30 \mu \mathrm{A}$ was obtained (Figure $2 \mathrm{~B}$, curve b), indicating that the immobilized laccase was bioelectrocatalytically active towards $\mathrm{O}_{2}$ electroreduction. Later the ThLc-LDG electrode was taken to phosphate buffer set at $\mathrm{pH} 7.4$, in which the enzyme is inhibited for $\mathrm{O}_{2}$ reduction ${ }^{11,16}$, but its production should be thermodynamically and kinetically favoured. A CV measurement showed an anodic wave that started at $0.95 \mathrm{~V}$ vs. NHE, i.e. quite close to the redox equilibrium potential of $\mathrm{O}_{2} / \mathrm{H}_{2} \mathrm{O}$ couple under these conditions (vide supra), reaching ca. $80 \mu \mathrm{A}$ at $+1.2 \mathrm{~V}$ (Figure $2 \mathrm{C}$, curve b). Subsequent scans caused the signal decrease when compared to the initial one, although current values of $c a .50 \mu \mathrm{A}$ at $+1.2 \mathrm{~V}$ were still measured (Figure $2 \mathrm{~B}$, curve c). For better understanding of the process, some control experiments were performed. It was particularly interesting to check the activity of the electrode in presence of $\mathrm{NaF}$, a natural inhibitor for the $\mathrm{O}_{2}$ reduction process catalyzed by $\mathrm{ThLc} \mathrm{c}^{11,12,17}$, resulting that under these conditions the $\mathrm{O}_{2}$ production pro- 
cess was not inhibited. The current intensity under $30 \mathrm{mM} \mathrm{NaF}$ was comparable to a typical experiment at $\mathrm{pH} 7.4$ in the absence of $\mathrm{NaF}$ ( $c f$. curves b in Figure 2C and 2D).
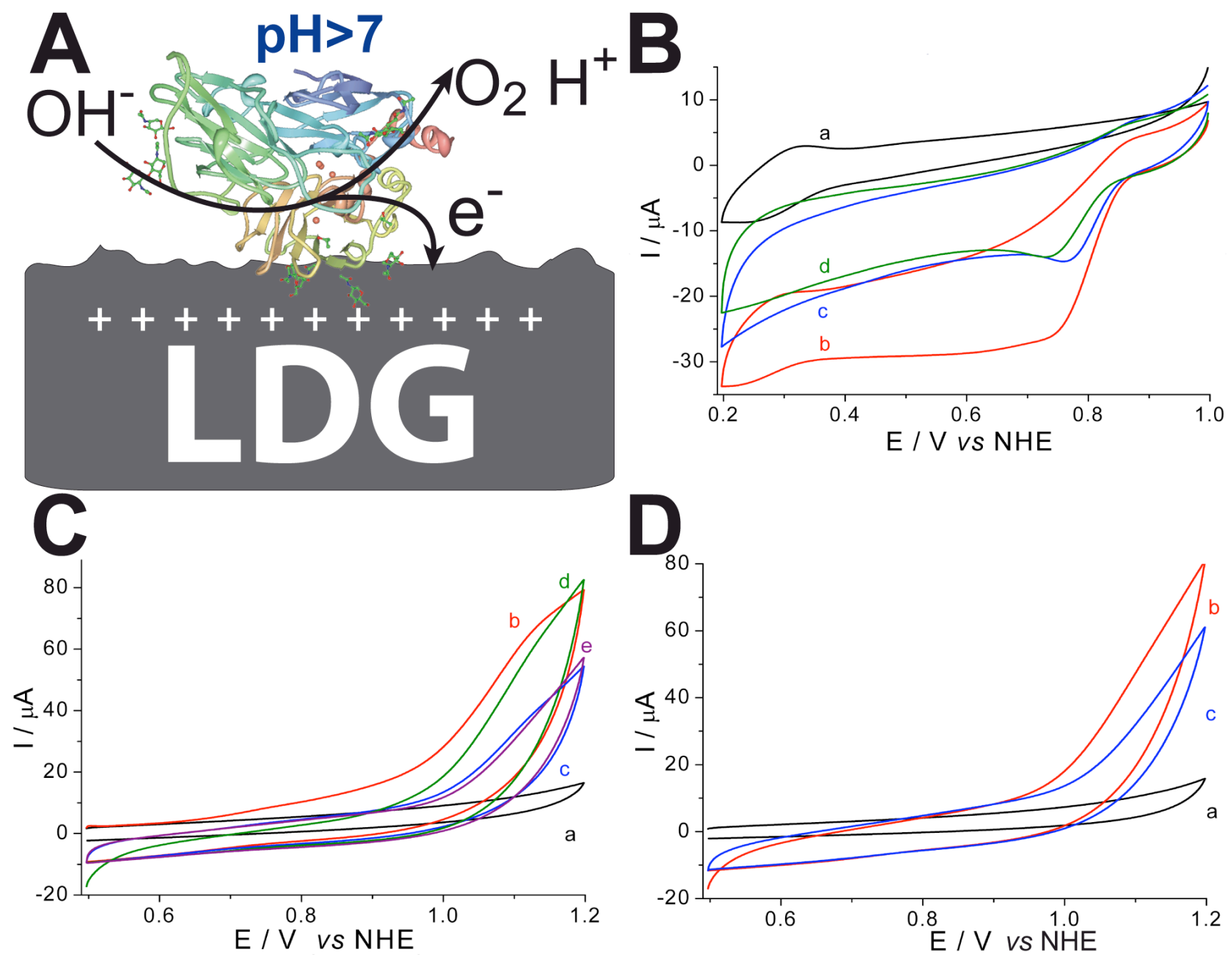

Figure 2. (A) Scheme showing the bioanode prototype based on ThLc. (B) CVs of $\mathrm{O}_{2}$ reduction: (a) background response of an enzyme-less electrode $\left(\mathrm{NH}_{2}-\mathrm{LDG}\right)$, (b) initial response of a ThLc-LDG electrode, (c) response after an anodic $\mathrm{O}_{2}$-production experiment, (d) response of the electrode after $18 \mathrm{~h}$ regeneration. (C) CVs of water oxidation: (a) background response of $\mathrm{NH}_{2}$-LDG electrode, (b) $1^{\text {st }}$ cycle of a just-prepared ThLc-LDG electrode, (c) $2^{\text {nd }}$ cycle of a just-prepared ThLc-LDG electrode, (d) $1^{\text {st }}$ cycle of a 18 h-old ThLc-LDG regenerated electrode, (e) $2^{\text {nd }}$ cycle of a 18h-old ThLc-LDG regenerated electrode. (D) CVs of water oxidation in the presence of $30 \mathrm{mM} \mathrm{NaF}$ : (a) $\mathrm{NH}_{2}-\mathrm{LDG}$ electrode, (b) $1^{\text {st }}$ cycle of ThLc-LDG electrode, (c) $2^{\text {nd }}$ cycle of ThLc-LDG electrode.

Despite the promising results obtained with ThLc-LDG electrode, some drawbacks were easily identified using this enzyme. Its activity was hampered after several $\mathrm{H}_{2} \mathrm{O}$ oxidation cycles and needed a resting period in optimum $\mathrm{O}_{2}$ reduction conditions, i.e. $\mathrm{pH} 4.2$ acetate buffer, for partially restoring the activity (Figure 2B, curve d). As mentioned above, ThLc does not show $\mathrm{O}_{2}$ reducing catalytic activity at neutral $\mathrm{pH}$ because it suffers reversible inhibition by hydroxyl ions. This effect explains the need of the regeneration stage at acidic $\mathrm{pH}$. Therefore, it is feasible that a different high redox potential laccase less optimized for acidic $\mathrm{O}_{2}$ reduction process but more resistant to hydroxyl inhibition may perform better in $\mathrm{O}_{2}$ evolution conditions, which is facilitated at neutral or even alkaline $\mathrm{pH}$ values. Recently we have reported a high redox potential laccase mutant ${ }^{18}$, ChUB, specifically designed to avoid anionic inhibitors, i.e. halides and hydroxyls, with sequence identity of $77 \%$ and similarity of $83 \%$ vs. ThLc (Figure 1). The mutant was the genetic product of several rounds of evolution and hybrid approaches to adapt 
the enzyme to the inclement conditions of human blood (i.e. $\mathrm{pH} 7.4$ with high chloride concentrations) (Figure S1).


Figure 3. (A) CVs showing the $1^{\text {st }}$ (solid line) and $2^{\text {nd }}$ (dash line) scans of (a) $\mathrm{NH}_{2}$-LDG electrode, (b) fresh ChUB-LDG electrode and (c) ChUB-LDG electrode after a 30 min chronoamperometry at a +1.2 $\mathrm{V}$ bias potential. (B) Chronoamperometric measurements for (a) LDG- $\mathrm{NH}_{2}$ electrode, (b) ThLc-LDG electrode and (c) ChUB-LDG electrode.

Using the same strategy as for ThLc immobilization, ChUB laccase was covalently bound to the surface of an aminoaryl modified electrode. The ChUB-LDG electrode was firstly tested for $\mathrm{O}_{2}$ reduction in the same conditions as ThLc-LDG for comparison (Figure S2). The electrochemical results showed that direct electron transfer from the electrode through the T1 site is less favoured than through the T2/T3 site, in agreement with the previous results for ChUB-LDG electrode ${ }^{18}$. Anodic CV measurements with the ChUB-LDG electrode at $\mathrm{pH} 7.4$ showed higher anodic currents than with the ThLc-LDG electrode (Figure 3A, curve b). Figure 3B shows typical chronoamperometric measurements for ChUBLDG and ThLc-LDG electrodes, whereas the result obtained for an aminophenyl-modified $\mathrm{LDG}\left(\mathrm{NH}_{2}-\right.$ LDG) electrode is shown as a control. It can be appreciated that both enzyme modified electrodes offer a much higher oxidation current than the control electrode.

Regeneration and durability of the modified electrodes were evaluated. The ThLc-LDG electrode maintained a significant anodic current measured by $\mathrm{CV}$, typically $70 \pm 10 \%$ of the initial one, along 3 experiments. Between each experiment a regeneration stage was carried out by $\mathrm{t} \geq 1 \mathrm{~h}$ immersion in 100 $\mathrm{mM}$ acetate buffer, $\mathrm{pH}$ 4.2. ChUB-LDG electrodes were checked along 3 days, setting them in the same regeneration stage. Additionally, we compared the CVs prior and after a chronoamperometry like the ones shown in Figure 3B. These experiments showed a major drawback for ThLc-LDG electrodes, as its activity was decimated even for its standard $\mathrm{O}_{2}$ electroreduction activity (Figure S3); contrary, the ChUB-LDG electrode maintained a high anodic response after the chronoamperometry (Figure 3A, curve c). 
Table 1. $\left[\mathrm{O}_{2}\right]$ and $\left[\mathrm{H}_{2} \mathrm{O}_{2}\right]$ produced by each type of electrode during a typical electrochemical chronoamperometry measure, coulomb efficiency towards $\mathrm{O}_{2}$ formation.

\begin{tabular}{|c|c|c|c|}
\hline Sample & {$\left[\mathrm{O}_{2}\right] / \mu \mathrm{M}$} & $\begin{array}{c}{\left[\mathrm{H}_{2} \mathrm{O}_{2}\right]} \\
/ \mu \mathrm{M}\end{array}$ & $\begin{array}{c}\text { C Effi- } \\
\text { ciency }\end{array}$ \\
\hline LDG-NH & $0.6 \pm 0.4$ & $0.5 \pm 0.3$ & ----- \\
\hline ThLc & $3 \pm 1$ & $0.5 \pm 0.5$ & 0.11 \\
\hline ChU-B & $2.9 \pm 0.7$ & $0.4 \pm 0.5$ & 0.16 \\
\hline
\end{tabular}

Enzyme-based colorimetric detection of possible reaction products $\left(\mathrm{H}_{2} \mathrm{O}_{2}\right.$ and $\left.\mathrm{O}_{2}\right)$ was carried out in triplicate to support the electrochemical results. The quantification of the products was performed inside an anaerobic chamber by running a 30 min chronoamperometry at $+1.2 \mathrm{~V} v s$. NHE in a $3 \mathrm{~mL}$ buffer solution pH 7.4 (Figure 3B). After each experiment the cell solution was split into three UV-VIS cuvettes for measuring either the blank spectrum, the $\mathrm{H}_{2} \mathrm{O}_{2}$ or the $\mathrm{O}_{2}$ produced by the enzymatic electrodes (Scheme S1). Approximately $3 \mu \mathrm{M} \mathrm{O}_{2}$ was produced by the enzymatic electrodes, whereas 5 times less $\mathrm{O}_{2}$ was detected on average in the control measurements. Additionally, the $\mathrm{H}_{2} \mathrm{O}_{2}$ detected in all three cases was comparable, so it can be attributed to non-enzymatic production of $\mathrm{H}_{2} \mathrm{O}_{2}$ by the LDG electrode. The results clearly indicate the ability of laccase modified graphite electrodes to produce mostly $\mathrm{O}_{2}$ at neutral $\mathrm{pH}$ by applying a potential of $+1.2 \mathrm{~V} v s$. NHE.

In summary, here we show that it is possible to use laccases together with an electroactive surface as a catalyst for the oxidization of $\mathrm{H}_{2} \mathrm{O}$ to produce majorly $\mathrm{O}_{2}$. A source of enzyme designed to increase the tolerance against hydroxyl anions yielded a more stable system, hinting that the configuration of the coordination sphere of both T1 copper site and T2/T3 copper cluster influences the durability of the enzymatic electrode. However, the lack of inhibition process in presence of a high concentration of $\mathrm{NaF}$ suggests that the intramolecular path of electron transfer between the T1 site and the T2/T3 cluster has not a major role in the $\mathrm{O}_{2}$ production mechanism ${ }^{19}$. The orientation of the enzyme on the electrode may play a role, as ChUB performs better and its $\mathrm{O}_{2}$ reduction electroactivity suggests it is majorly oriented with its T2/T3 cluster facing the electrode, contrarily to ThLc. On the other hand, we do not think that the water oxidation activity is caused by a major structural change of the laccases' conformational structure during immobilization, as both enzymes retain $\mathrm{O}_{2}$-reduction activity. For this bioelectrochemical process we propose a different mechanism than just reversing the natural one of laccase ${ }^{20}$. Instead the T2/T3 copper cluster might behave as a copper complex ${ }^{13}$, taking $\mathrm{OH}^{-}$anions from the solution and becoming oxidized due to the high potentials applied at the electrode. If this is the case it could imply the formation of either a $\mu$-peroxide or a bis $(\mu$-oxo) bridge $(\mathrm{Cu}-\mathrm{OO}-\mathrm{Cu})$ intermediate, as suggested for $\mathrm{Cu}$ complexes electrocatalyzing $\mathrm{O}_{2}$ production ${ }^{13}$. However, this hypothesis remains to be verified. Nevertheless, our results open a way to decrease considerably the overpotentials for electrochemical $\mathrm{H}_{2} \mathrm{O}$ splitting.

To conclude, our work shows one of the best solutions, viz. usage of biological catalysts, to a very urgent task existing nowadays: to intensify $\mathrm{H}_{2} \mathrm{O}$ electrolysis and to reduce energy consumption in order to meet the requirement of sustainable production of $\mathrm{H}_{2}$ and $\mathrm{O}_{2}$ in large scale. Directed evolution provides the tools to find new laccase mutants that may enhance the enzyme stability and performance for its newfound reversible reaction, allowing for a lower overpotential water splitting process. T2/T3 laccase cluster may also inspire efficient biomimetic catalysts for $\mathrm{H}_{2} \mathrm{O}$ oxidation. Future work will target unveiling the process' mechanism and test alternative mutant laccases and other immobilization strategies.

\section{ASSOCIATED CONTENT}

Supporting Information. Additional material containing experimental details, the sequence alignment of ChU-B and ThLc and CVs for $\mathrm{O}_{2}$ reduction laccase-modified electrodes is provided. This material is available free of charge via the Internet at http://pubs.acs.org.

\section{AUTHOR INFORMATION}




\section{Corresponding Authors}

Marcos Pita (marcospita@icp.csic.es) \& Antonio L. De Lacey (alopez@icp.csic.es) Instituto de Catalisis y Petroleoquimica, CSIC. C/ Marie Curie, 2, L10. 28049 Madrid, Spain.

\section{Funding Sources}

No competing financial interests have been declared. This research was funded by the FP7 projects "FP7-PEOPLE-2013-ITN-607793", "FP7-KBBE-2013-7-613549”, and the Spanish National Program project "MINECO-CTQ2012-32448".

\section{ACKNOWLEDGMENT}

M. P. acknowledges the 2009 Ramon y Cajal program from the Spanish MINECO.

\section{REFERENCES}

(1) Mallouk, T. E.. Nat. Chem. 2013, 5 (5), 362-363.

(2) Park, S.; Shao, Y.; Liu, J.; Wang, Y. Energy Environ. Sci. 2012, 5 (11), 9331-9344.

(3) Wang, M.; Wang, Z.; Gong, X.; Guo, Z. Renewable Sustainable Energy Rev. 2014, 29, 573-588.

(4) Armstrong, F. A.; Belsey, N. A.; Cracknell, J. A.; Goldet, G.; Parkin, A.; Reisner, E.; Vincent, K. A.; Wait, A. F. Chem. Soc. Rev. 2009, 38 (1), 36-51.

(5) Shafaat, H. S.; Ruediger, O.; Ogata, H.; Lubitz, W. Biochim. Biophys. Acta 2013, 1827 (8-9), 9861002.

(6) Kato, M.; Cardona, T.; Rutherford, A.W.; Reisner, E. J. Am. Chem. Soc. 2013, 135, 10610-10613.

(7) Watanabe, N.; Devanathan, M. A. V. J. Electrochem. Soc. 1964, 111 (5), 615-619.

(8) Morozova, O. V.; Shumakovich, G. P.; Gorbacheva, M. A.; Shleev, S. V.; Yaropolov, A. I. Biochemistry (Moscow) 2007, 72 (10), 1136-1150.

(9) Solomon, E. I.; Sundaram, U. M.; Machonkin, T. E. Chem. Rev. 1996, 96 (7), 2563-2605.

(10) Berezin, I. V.; Bogdanovskaya, V. A.; Varfolomeev, S. D.; Tarasevich, M. R.; Yaropolov, A. I. Doklady Akademii Nauk SSSR 1978, 240 (3), 615-618.

(11) Shleev, S.; Tkac, J.; Christenson, A.; Ruzgas, T.; Yaropolov, A. I.; Whittaker, J. W.; Gorton, L. Biosens. Bioelectron. 2005, 20 (12), 2517-2554.

(12) Cracknell, J. A.; Vincent, K. A.; Armstrong, F. A. Chem. Rev. 2008, 108 (7), 2439-2461.

(13) Chen, Z.; Meyer, T. J. Angew. Chem. Int. Ed. 2013, 52 (2), 700-703.

(14) Gutierrez-Sanchez, C.; Jia, W.; Beyl, Y.; Pita, M.; Schuhmann, W.; De Lacey, A. L.; Stoica, L. Electrochimica Acta 2012, 82, 218-223.

(15) Gutierrez-Sanchez, C.; Pita, M.; Vaz-Dominguez, C.; Shleev, S.; De Lacey, A. L. J. Am. Chem. Soc. 2012, 134 (41), 17212-17220.

(16) Clot, S.; Gutierrez-Sanchez, C.; Shleev, S.; De Lacey, A. L.; Pita, M. Electrochemistry Communications 2012, 18, 37-40.

(17) Pita, M.; Gutierrez-Sanchez, C.; Olea, D.; Velez, M.; Garcia-Diego, C.; Shleev, S.; Fernandez, V. M.; De Lacey, A. L. J. Phys. Chem. C 2011, 115 (27), 13420-13428.

(18) Mate, D. M.; Gonzalez-Perez, D.; Falk, M.; Kittl, R.; Pita, M.; De Lacey, A. L.; Ludwig, R.; Shleev, S.; Alcalde, M. Chem. Biol. 2013, 20 (2), 223-231.

(19) Xu, F.; Berka, R. M.; Wahleithner, J. A.; Nelson, B. A.; Shuster, J. R.; Brown, S. H.; Palmer, A. E.; Solomon, E. I. Biochemical Journal 1998, 334, 63-70.

(20) Solomon, E. I.; Augustine, A. J.; Yoon, J. Dalton Transactions 2008, (30), 3921-3932. 